УДК 792.05(477)(091)

DOI: $10.31866 / 2616-759 x .2 .2018 .153228$

Юдова-Романова Катерина Володимирівна, кандидат мистецтвознавства, доцент, Київький національний університет культури і мистеитв, Київ, Україна iudovakateryna@gmail.com

ORCID: https://orcid.org/0000-0003-2665-390X

\title{
ЗАСОБИ ПЛАСТИЧНОГО ОФОРМЛЕННЯ СЦЕНІЧНОГО ПРОСТОРУ (3 ІСТОРІЇ УКРАЇНСЬКОГО ТЕАТРУ)
}

Метою статті $є$ розгляд еволюції театрального простору українського театру 3 погляду архітектурно-технічного забезпечення його пластичного оформлення. Автором використані такі методи дослідження: критичного аналізу - в опрацюванні наукової літератури з історії театрального мистецтва, архітектури та сценічного дизайну 3 метою реферування інформації стосовно теми дослідження; мистецтвознавчого аналізу - для співвіднесення пластики сценічного простору вистав та їхнього змістовного наповнення; синтезу - для поєднання різних характеристик просторовотехнічного забезпечення українського театру періоду XVII - XIX ст.; індукційний - для вивчення хоча й фрагментарних, але типових прикладів просторово-технічного забезпечення вистав означеного періоду; гіпотетичний, системний та узагальнюючий для формулювання висновків. Наукова новизна. У дослідженні вперше осмислюється еволюція театрального простору українського театру 3 погляду засобів його пластичного оформлення. Висновки. Твори сценічного мистецтва, маючи дієву структуру, матеріалізуються в певному сценічному просторі; відповідно до різновидів українського театру XVII - XIX ст. - шкільний театр, церковно-релігійна драма, вертеп, кріпацький театр, публічний театр, домашній театр, «редут», балагани, сільські народні театри, театри мистецьких освітніх закладів - існували специфічні форми та засоби пластичного оформлення їхнього сценічного простору; українському театру властивий простір і закритого (приватні оселі, громадські місця, культові споруди), якому притаманні широке застосування предметних комплексів, і відкритого типів (локації природного ландшафту) з декораціями спрощено-мобільного характеру; характерним для вистав у приміщеннях церкви було використання світлових ефектів, культової атрибутики та театральної бутафорії; засоби пластичного оформлення сценічного простору вертепу - двоповерхова мобільна скринька із умовно знятою «четвертою стіною» та набір лялькових персонажів; мандрівний спосіб організації діяльності та економічна скрута переважної більшості театральних колективів в Україні на початку XIX ст. не сприяли розвитку сценографії та театральної техніки; матеріальнотехнічне забезпечення сільських театрів, зокрема на Галичині, було відносно достойним.

Ключові слова: історія українського театру; сценічний простір; засоби пластичного оформлення; Дмитро Антонович. 
Постановка проблеми. Сценічне мистецтво - комплексне явище, що органічно інтегрувало в собі різні види мистецтва: театральне мистецтво, художню літературу, архітектуру, кіномистецтво та образотворче, музичне, хореографічне, естрадно-циркове та інші мистецтва. Місце і значення кожного 3 інтегрованих видів мистецтв у конкретному творі сценічного мистецтва сценічній постановці - визначається колективною творчістю його авторів і в підсумку визначає видову й жанрову приналежність сценічної постановки. Твір сценічного мистецтва - матеріалізоване втілення задуму авторів, сценічна постановка, яка, грунтуючись на літературному та режисерських задумах, матеріалізується перед глядачами в живому виконанні. Саме безпосередньо впливаючи на органи чуттів - зору, слуху, іноді нюху або дотиком, твір сценічного мистецтва набуває факту його підготовлення й існування. Але $з$ яких би синтетично інтегрованих видів мистецтва не народжувався твір сценічного мистецтва, він завжди має матеріалізуватися перед глядачами он-лайн у певному публічному просторі.

Сьогодні питання осмислення простору та розуміння правил його існування в художній культурі залишається однією із найскладніших та багатовекторних проблем. При цьому особливості функціонування творів сценічного мистецтва в просторі, зокрема питання архітектурно-технічного забезпечення їхнього дизайну, досі потребують наукового мистецтвознавчого дослідження.

Аналіз останніх досліджень і публікацій. Поняття категорії простору було введено в обіг теорії культури лише в ХX ст. Наразі розробленість теми театрального простору щодо архітектоніки сцени, іiі дизайну та архітектурнотехнічного забезпечення $€$ актуальним завданням для сучасного мистецтвознавства. Тема співвідношення художнього та фізичного простору розглядається в працях М. Бахтіна, П. Флоренського, А. Бергосона, М. Гайдеггера, О. Шпенглера, Х. Ортега-і-Гасета. 3 погляду театральної теорії i практики простір вивчали А. Аппіа, Г. Крег, А. Арто, М. Рейхардт, Вс. Мейєрхольд, Лесь Курбас. У XX ст. дослідники (Р. Барт, П. Паві, Ю. Лотман, Г. Юберсфельд, М. Поляков, Е. Суріо й ін.), аналізуючи різні просторові системи театру, зосереджували свою увагу на розвиткові театральної семіотики.

Питання історії i традицій художньо-декораційного оформлення українського театру висвітлювались у мистецтвознавчих роботах I. Верикіської, Г. Веселовської (2010), А. Драка, О. Островерх, В.Фіалка. Не залишає поза увагою проблеми сценічного простору у своєму міждисциплінарному філософському дискурсі Н. П. Чечель (2005). Сценографи українського театру М. Френкель, Д. Лідер, М. Левитська - у своїх роботах переважно зосереджувались на аналізі сценографічної практики. Львівський архітектор В. Проскуряков предметом свого наукового дослідження обрав театральний простір в архітектурному аспекті. В. Базанов зосереджував свої дослідження у напрямку вивчення естетичних функцій театральної техніки, що визначає пластичний стиль вистави, історії та сучасності архітектури театральних приміщень, технології сцени, організації роботи художньо-постановочної частини театрів. Л. Михайлов вузькою сферою своїх мистецтвознавчих досліджень обрав технічні засоби оформлення саме сучасного естрадного 
видовища. Т. Астаф’єва вивчає нові технології в сучасному постановочному процесі на матеріалах науково-практичного дослідження театрального мистецтва Санкт-Петербурга (2011). М. Крипчук у своїх дослідженнях аналізує сценічний простір сучасних театралізованих святкових масових видовищах просто неба (2018), а також особливості, принципи й засоби їхнього художнього оформлення в контексті колективної творчості художника й режисера. Отже, театральний простір визначає широкий спектр векторів для досліджень (2011).

Мета статті - розглянути на матеріалі історико-театрознавчого дослідження Дм. Антоновича «Триста років українського театру» еволюцію театрального простору українського театру з погляду архітектурно-технічного забезпечення його пластичного оформлення.

Виклад основного матеріалу. Особливим різновидом сфери дизайнерської діяльності є сценічний дизайн. Він містить в собі родові ознаки дизайну як художньої проектно-конструкторської діяльності, спрямованої на створення та оформлення предметного середовища, але має відмінність від інших видів дизайну. Сценічний дизайн передбачає конструювання такого простору, в якому має безпосередньо відбуватися візуальна сценічна дія (активність). В організації цього простору поряд із художником-дизайнером беруть участь актори, режисери, композитори, хореографи й ін. Відображаючи широкий спектр концепцій сучасного мистецтва, його образно-змістовні та формально виразові якості, сценічний дизайн є яскравим синтетичним явищем, у якому знаходять віддзеркалення характерні художні тенденції часу.

Дослідниця еволюції просторових систем українського драматичного театру О. Островерх зазначає: «простір, будучи однією 3 найбільш репрезентативних категорій сучасної художньої культури, інтерпретується, насамперед, як дієва структура» (2007, с.27). При цьому мистецтвознавиця зосереджує свою дослідницьку увагу лише на театральному просторі драматичних вистав, дотримуючись одного з найвагоміших визначень цього терміна, запропонованого П. Паві в «Словнику театру». За концепцією П. Паві, простір (у театрі) складається зі сценічного простору - простору сценічного майданчику, де відбувається сценічна дія; ігрового простору - простору присутності гри актора; простору глядача, де він комунікує зі сценічним та ігровим просторами; драматичного простору - простору, про який ідеться у виставі, читач або глядач вибудовує його у своїй уяві; сценографічний простір (або ще театральний простір) - сценічний простір, котрий можна визначити як простір, де перебуває публіка й актори під час вистави; він виконує функцію зв’язку між публікою та акторами (Паві, 2006, с.362-363). Але при такому підході відбувається звуження поняття «сценічний простір» до розуміння його лише як частити простору в театрі, тобто обмежується тлумачення «сценічного простору» як «простору сцени». Хоча більш прийнятним видається трактування сценічного простору як «дієвої структури» (за О. Островерх), у якій перед глядачами розгортається дійство (дія - лат. actio), видовище в безпосередньому виконанні - драматичне, музичне, хореографічне, піротехнічне, ароматичне, водне й ін.

Розглянемо театральний простір та його дизайнерсько-архітектурнотехнічне облаштування в українському театрі за матеріалами дослідження історії українського театру Дм. Антоновича. 
Посилаючись на випадкову, хоч i занотовану дату відліку історії українського театру, Дм. Антонович зазначає, що коріння українського театрального мистецтва знаходиться в дохристиянській обрядовості. «Розуміється, було б правильніше починати огляд розвиту українського театру не 3 тої припадкової дати ${ }^{3}$ а від перших зародків українського театру, які [...] закладено ще в дохристиянських обрядових діях; в українців передовсім в весільному обрядові, а також у веснянках, колядках, купальській справі й ін..» (1925, с.8). Факт виконання інтермедій на ярмарку Дм. Антонович пов’язує 3 діяльністю студентів духовних семінарій, які підчас канікул, мандруючи містами й селами, розігрували просто неба драматичні сценки або вистави на релігійну тематику. Традиція ця пішла від єзуїтських шкіл: «На Україні театральні вистави особливо старанно плекали в своїх школах єзуїти, які в сімнадцятому віці захопили в свої руки справу виховання панської молоді і використовували шкільний театр в своїх цілях католицької і польської пропаганди» (Антонович, 1925, с.9). Згодом, на думку Дм. Антоновича, «ті шкільні драми, що їх у XVII столітті культивували єзуїти по своїх школах та колегіях, і які в боротьбі проти єзуїтської агітації засвоїли собі українські школи, мали переважно вже мішаний характер містерій чи міраклів отриманих з мораліте...» (1925, с.9).

Саме в духовних семінаріях зароджуються традиції икільного театру в Україні. При цьому виконавське мистецтво шкільного театру потребувало неабиякої підготовки, яку й отримували семінаристи в стінах духовних академій та семінарій. Дм. Антонович наголошує: «П'єси шкільного репертуару вимагали відповідного виконання, і школа мусила чимало научати акторському ділу, мусила навчити величавим викінченим рухам, мальовничим позам, виразній декламації, музикальній модуляції. Одним словом, уміння актора виконавця було дуже нелегке; без спеціальної науки на сцену йти було годі, і під цим виглядом мистецтво актора стояло не низько, і дилетантизмові місця не було. Тому зрозуміло, що тільки школярі, які проходили в школах ту нелегку науку, могли бути акторами, могли виконувати п'єси на шкільних виставах, а потім товариствами розходитися на час вакацій, або після школи і робити вистави для заробітку».

Далі Дм. Антонович зазначає, що школярі, формуючи мандрівні оркестри, хори або трупи, переїжджали від села до села, від ярмарку до ярмарку, від хати до хати, виступаючи скрізь по всій Україні - «по панських будинках, по козацьких оселях, по коршмах, на ярмарках» (1925, с.30). Отже, шкільні «вистави були загальноприступні для всіх». Відповідно до організації навчального процесу у семінаріях корелювалось і театральне життя - воно особливо пожвавлювалось «на різдвяні та великодні свята. Але найбільше

\footnotetext{
${ }^{3}$ Дм. Антонтович має на увазі документальний доказ, що 29 серпня 1619 р. у Камінці Струмиловій, недалеко від Львова, на ярмарку в день ушанування пам'яті Іоанна Хрестителя була поставлена по новозавітньому сюжету віршована п'ятиактна драма Якуба Гаватовича «Tragaedia albo wiserunek śmierci prześwietego Jana Chrzciciela, przesłańca Bożego» («Трагедія, або Образ смерті пресвятого Іоанна Хрестителя, посланця Божого». Перекл. $з$ польської К. В. Ю.-Р.), між актами якої вперше на українській сцені було поставлено українською мовою драматичні твори: інтермедії, або інтерлюдії «Про кота в мішку» і «Кращий сон» (1925, с.7).
} 
урочистими це були спеціяльні вистави в школах і особливо в Київській Академії...» (Антонович, 1925, с.39).

У 60-х роках XVIII ст. ректором Самуїлом Миславським у Київській Академії (Києво-Могилянська академія) було заборонено театральні вистави в стінах Академії, але «спудеї» із викладачами, не бажаючи покидати улюбленої справи, «з виставами вийшли за стіни своєї alma mater під открите небо». «Маєві рекреації», як називали учні й педагоги такі позашкільні виїзди на природу, наприклад, для київської Академії «нагору Скавику між ярів, біля урочища, що називається Глубочиця» (Антонович, 1925, с.31). обов’язково поряд із забавами, співом кантів містили театральні постановки. Дм. Антонович стверджує, що «діалоги виставлялися часто на свіжому повітрі, без спеціяльних декорацій» (1925, с.31).

Дм. Антонович також свідчить про мандрівний і стаціонарний способи організації діяльності труп шкільного театру та способи художньопостановочного забезпечення вистав: відповідно, спрощено-мобільного та, за деякими свідченнями, на прийнятному матеріально-технічному рівні. «Що до обстановки вистав, то вона не завжди і не скрізь була однаково проста або вибаглива. Коли товариство мандрувало в невеликому числі членів, роблячи вистави, співаючи канти або партеси, допомагаючи в церковних службах, то, розуміється, ні декорацій, ні обстанови із собою було не носити. В ліпшому разі можна було взяти з собою дещо з театральної гардероби. Простіші вистави робилися просто в хаті і без всякої обстанови, а враження на глядачів справлялося тільки текстами виконаних п’єс та майстерністю декламації і взагалі виконання. Але коли вистави робилися в самих школах, то вже до них пристосовувалися найпотрібніші декорації» (Антонович, 1925, с.32). Далі, посилаючись на О. Веселовського, автор зазначає, що шкільні декорації були досить прості й примітивні: «шкільна містерія порядкувала певне тільки чисто шкільними-ж засобами постанови; класна кімната, простирадло замість завіси, фантастичні вбрання біблейських та євангельських осіб, перуки, та бороди, iз льняного прядива, от чим, може бути, обмежувалась вся вбога постанова» (Цит. за Антоновичем, 1925, с.32).

Порівнюючи художньо-постановочне забезпечення сцени шкільного театру в Україні та європейського містеріального театру цієї ж доби, О. Веселовський нарікає на скромність в оформленні першого, на його «дитиняче становище»: «Як далеко їй до трьох-поверхової сцени західної містерії, чи до цілих вулиць, обставлених риштованням та помостами, наділеними багатьма причандалами, хоч і трохи грубуватими на вигляд, покритими блакитним полотном з зорями замість неба; як далеко від цих щелепів пекла, райських садків, сцен мордування та урочистих процесій!» (Цит. за Антонович, 1925, с.32). При цьому Дм. Антонович додає, що погляд О. Веселовського не зовсім категоричний і стосується «з певними застереженнями, хіба до шкільних постанов в менших провінціяльних школах» (Антонович, 1925, с.32).

Історик українського мистецтва К. Широцький, досліджуючи питання розвою шкільного театру заперечував думку О. Веселовського щодо примітивності й убогості пластичного оформлення сценічного простору у ньому. Вчений наполягає, «що театральна обстанова вистав Київської 
Академії [...] була дуже вибагливою, мала багато декорацій, світових ефектів, досить розвинену театральну техніку. Так в п’єсі «Алексій чоловік Божий» на «плацу», т. є. «на сцені з одного боку був виведений рай, певно на містках, над сценою, 3 другого боку пекло й в ньому змій. В раю ангели славили бога і бесідували між собою; потім «нисходили од ступеней висоти» до Олексія на землю - значить на сцені була й земля. Олексій стояв на роздоріжжю: Юнона й Фортуна зманювали його до веселого життя й простелювали килим, широким шляхом «сбігаючий вниз до ада». Але Virtus застерігала Олексія й простелила йому килим, ідучи до неба - «ту змій рот роззявив і дим іспущав»... Усе це було на сцені показано з усіма подробицями...(Антонович, 1925, с.36).

Далі Дм. Антонович, цитуючи К. Широцького, наводить приклади масштабних постановок шкільного театру у Києво-Могилянській Академії: згадується вистава 1685 року «Дійство на страсті Христові» 3 декораціями страстей та 12 юнаками, увінчаними вінками, і 12 зірок; постановка «Свобода от віков вожделенної натурі людській» 1701 року. «Там були виведені: рай, золоте жниво, алегорії та ін. У четвертій сцені другого акту меркли сонце, місяць і звізди, мерці вставали з гробів; в останній сцені того ж акту і в третім акті на кону показувалось хвилююче море з потопаючим серед хвиль кораблем; щоби врятуватися мореходці кидають Іону в хвилі; там його лигає здоровенний кит і в пятій сцені викидає його на берег». При цьому автор зазначає, що «поставити таку пьєсу можна було, тільки маючи під руками усякі прилади, декорації, машини, автомати» (Цит. за Антоновичем, 1925, с.36). 3 відомостей про сценічне втілення діалогу «О страданіях спасителя» стає зрозумілим, «що для зображення Христа, ангелів й других святих, або історичних особ, потрібувалися осібні маски [...], або уміння покривати лице гримом» (Цит. за Антоновичем, 1925, с.37).

К. Широцький також стверджує, що в шкільному театрі, зокрема Київської Академії, була розвинені «усякі пристрої «махини й літання»» - механічна техніка для показу вистав: наприклад, «в «Ужасной ізміні сластолюбивого життя» від грому розступається земля, ангели несуть на не небо душу Лазаря і т. д.» (Цит. за Антоновичем, 1925, с.37). Окрім цього, сценічний майданчик мав мати «певну глибину далі і картину», що надавало створювати мальовану перспективу у живописних декораціях. Підводячи підсумок, К. Широцький стверджує, що «декорації готовилися власними силами артистів», при цьому в роботі над виставами не можна було обійтись без активної безпосередньої участі «свого архітектора, сценаріуса, декоратора, кравця, а певне співців і танцюристів» (Цит. за Антоновичем, 1925, с.37). До цього переліку можна додати піротехніка, столяра-механіка, художника-гримера.

Містеріальний театр першої половини XVII ст. не залишив багатого матеріалу про технічне забезпечення вистав. Історики В. Рєзанов, К. Широцький, а згодом Дм. Антонович збирали інформацію по крихтам 3 різних джерел - у ремарках і текстах п’єс, іноді в підручниках, за господарськими та інвентарними записами, ілюстративним матеріалом до текстів, народними лубочними картинками тощо. Так, наприклад, з ремарок до містерії «Слово о збуренню пекла» ясно, що на сцені виставлялись тверді мальовані декорації 3 функціональними можливостями у поєднанні 
зі сценічними світловими ефектами. Дм. Антонович, цитуючи ремарки, зауважує: «На очах у глядачів Христос «биєт корогвою, і бисть тако сокрушишася врата» і потім зразу все пекло представлене на кону освітлюється: «в той час ворота і лантухи сокрушишася і входить Христос во пекло і освіщаєт ясним своїм промінем». - Самі врата адові і пекло в цій містерії мало бути представлене, як середнєвічний, може готицький замок, з підзємними мостами, що видно зі слів наказу люцифера до своїх жовнірів-бісів:

А ви ворота желізніє рихло зачиняйте

I зводи звівши лантухами заволікайте,

I колодками моцними і твердими замикайте!» (Цит. за Антоновичем, 1925, с.33).

Шкільна драма за своєю змістовно-тематичною та організаційною суттю завжди була тісно пов'язана із церквою. Свідченням цьому є суто релігійне спрямування п’єс, приналежність виконавців до категорії служителів культу школярів духовних семінарій та використання приміщення культових споруд для показу вистав. Так, наприклад, 3 тексту інтермедії до драми «Comunia duchowna s.s. Borysa y Hleba», яка виконувалася в єзуїтській колегії наприкінці XVII ст. у м. Полоцьку, з діалогу героїв стає зрозумілим, що вона мала виконуватись у костьолі, оскільки в ньому згадується костьольний орган (Антонович, 1925, с.33-34).

Неодноразово поряд із використанням приміщення церкви, церковного органу згадуються й інші церковні аксесуари, приміром, плащаниця, які в купі ставали невід'ємною складовою декораційного оформлення сценічного простору вистав шкільного театру.

Ремарки до тексту п’єси «Царства натури людской», виставленої у 1706 р. свідчать про неабиякої складності технічні, звукові та світлові художньопостановочні ефекти - так, «наприклад у другій сцені першого акту зауважено, що всемогутня рука благословить 3 небес людську натуру; в п’ятій сцені тої ж пьєси сказано, що бог з неба посилає на землю громи і блискавиці, що свідчить про те, що користувалися в постановці світляними ефектами, [...] в третій сцені другого акту бог являється в огняній купині» (Антонович, 1925, с.35). На жаль, описи генерованих ефектів не містять записів способу їхнього втілення. Такий факт може бути виправданий бажанням постановників зберегти таємниці їхнього втілення, що в свою чергу пояснюється, 3 одного боку, економічними причинами, а з іншого, - не бажанням церкви допустити в глядачів руйнацію ілюзї дійсного чуда, з вірою в яке вони приходили на вистави до церкви.

Різносторонній інформаційний матеріал про облаштування та оздоблення сцени шкільного театру черпають історики театру з ілюстрацій до текстів п’єс, які подавались іноді не лише як візуалізація подій, але й слугували вказівниками для виконавців. Так, наприклад, на ілюстраціях до п’єси Симеона Полоцького «История или дійствіє Євангельской притчи о блудном сині, биваємоє в літо Р. Х. 1685», пише Дм. Антонович, «представлено те саме театральне помешкання 3 піднятою завісою і на кону одбуваються постепенно всі сцени притчі» (1925, с.37). Автор подає опис зображеної на ілюстрації сцени: «Самий кін збудовано на високому помості, по боках кону дві колони, на яких вгорі лежить перекладина, до якої прикріплено завісу. На авансцені, 
в рампі стоїть ряд каганців, освітлюють сцену. На кожному рисункові представлено лавку з перилом першого ряду глядачів, нарисованих зі спини, бо сидять лицем до сцени. Глядачі сидять в капелюхах. Обстанова на кону ріжних сценах зміняється. Там, де дія одбувається в середині хати, то з усіх трьох боків поставлено по стіні і лише в залежності від дії хату обставлено: в сцені 3 любодійницями в кутку стоїть ліжко, в сцені гри в зернь стоїть стіл, на якому грають, а посуд переставлено додолу, в сцені, де отець бенкетує, радіючи, що вернувся блудний син до отчого дому, на середині кону стоїть стіл з осудом і стравою, а за столом лава, на якій сидить старий батько. Коли ж сцена має одбуватись на дворі, то там ліву від глядача декорацію прийнято, натомість залишено одвертий прохід, i на кону зістається враження ніби відкритої надвірної галєрійки, або лоджії, як наприклад, в тій самій сцені, де любо дійниці вигонять блудного сина». Такий детальний опис надає нам можливість чітко уявити саму сцену, ïi архітектурно-технічне забезпечення і зрозуміти принципи світлового оформлення, розміщення глядачів, відчути динамічність та збагнути функціональне призначення декорацій. Не залишається поза авторською прискіпливою увагою i костюми та грим виконавців: «Одежи виконавців, особливо молодих панів, звичайні, як ходили на Україні школяри; на актьорах, що виконують старших людей, трохи фантастичні, довгі ряси киреями наверх, мабуть такі, якими уявляли собі тоді біблійські одяги». Далі детально подається опис виконавця «прилогу»: «він задрапірований в широку альмавіву, на ногах має черевики, панчохи та тісні штани, на голові клинчату шапку на три кінці» (Антонович, 1925, с.38).

Нажаль, історія мало зберегла імена майстрів, чиїми зусиллями втілювалось на сцені художнє оформлення вистав. Тим цінніша пам'ять про такого собі майстра Чижинського відомого 31675 року, який «завідував театральними постановками в Київській Академії і придумував декорації та орудував всім знаряддям до вистави» (Антонович, 1925, с.38).

Вистави школярів Київської Академії ще виконувались «певне протягом майже цілого вісімнадцятого віку, a, можливо, навіть на початку дев’ятнадцятого, поки іiі не закрито 1817 року» (Антонович, 1925, с.39). Але 3 другої половини XVIII ст. творчого розвитку в шкільній драмі не відбувалось. Проіснувавши протягом XVII-XVIII ст., під утиском імперської політики російського самодержавства щодо України, шкільний театр припинив своє існування і переходу до світського театру не здійснив. Мостом до світської комедії стала весела інтермедія.

Особливе місце в історії українського театру займає вертеп - один 3 різновидів лялькового театру. Він у період гонінь на українську культуру, літературу, мову, мистецтво, театр другої половини XVIII ст. виявився живучішім, незважаючи на всі заборони, і вижив завдяки студентам, а пізніше бурсакам духовних академій та семінарій. Для них це було традиційною художньою розвагою під час канікул та вірним способом «заробити на хліб і науку» (Антонович, 1925, с.42). Незважаючи на всілякі заборони особливо «в самому Київі, все ж поза Київом, в стороні від начальницького ока продовжували ходити з вертепом і зустрівали прихильність і ласку по селах та хуторах широкої України» (Антонович, 1925, с.43). 
«Коли появився вертеп на Україні, раніше чи пізніше шкільної драми, сказати важко. - пише Дм. Антонович. - Найстаріша і то зовсім не певна відомість про вертеп сягає 1591 року; Франко і В. Перетц гадають, що вертепні вистави на Україні з’явилися і в першій половині XVII віку... ( 1925, с.45).

Вистави вертепного лялькового театру розігрувались у спеціальній двоповерховій переносній скрині, що традиційно мала вигляд двоярусної хати зі знятою «четвертою стіною». Наприклад, Галагівський вертеп (Григорія Галагана) 3 маєтку у Сокоринцях на Полтавщині, що нині виставляється в експозиції в Києві у Музеї театрального, музичного та кіномистецтва України, «мав біля півтора метра заввишки і трохи більше одного метру завширшки. По-за задньою стінкою вертепу сидить виконавець, що водить ляльками і говорить за них на ріжні голоси» (Антонович, 1925, с.43).

Самодержавна політика Росії проти українського слова торкнулась не лише друкованого слова, шкільного театру, але i народного вертепу - він був заборонений.

У кінці XVIII ст., власне указом Катерини II від 3 травня 1783 р. на Лівобережжі й Слобожанщині остаточно запроваджується кріпацтво. На грунті володіння кріпаками на Україні поширюється, хоч і не так активно, як в Московії, традиція існування кріпацьких театрів у поміщицьких садибах та маєтках. В Україні в кріпацьких театрах виконавське мистецтво швидко розвивається і здобуває визнання як в Росії, так закордоном. Прикладів існування кріпацьких театрів на Україні чимало. Дм. Антонович, наприклад, згадує: «В Полудневій, українській частині Курщини коло Суджі мав кріпацький театр граф Волкенштейн, на Чернігівщині мав, здається, свій театр в Ляличах граф Завадовський і пізніше в селі Спиридонова Буда поміщик Дмитро Ширай [...]. На Полтавщині мали кріпацький театр Трощинський в селі Кибинцях і Кобеляцький маршалок Гавриленко. У Гавриленко в маєтку Озерки Кобеляцького повіту був навіть мурований будинок для театру з трьома ложами і партером» (Антонович, 1925, с.54). Тут виступав М. Щепкін.

«На правому березі Дніпра мали свої кріпацькі театри дехто 3 польських магнатів» (Антонович, 1925, с.54). Так, наприклад, Тульчинський палацовий ансамбль родини Потоцьких, який було збудовано 1782 р. Станіславом Щенсним-Потоцьким, крім графського палацу, на території маєтку поміж інших приміщень для різних служб - конюшні, манеж, кордегардію (приміщення для військового караулу, а також для утримання арештованих під вартою), будинок для управляючого маєтком, торгові ряди, де продавали вироби тульчинських мануфактур, - зокрема, містив садибний театр - одноповерхову цегляну споруду (Цит. за Чубіна, 2010, с.150). Репертуар театру складався з 5-7 опер та 2-3 концертів, трупа налічувала до 200 акторів. Перебуваючи в Тульчині влітку 1811 р. французький письменник Лагард в своїх листах, детально описуючи свій відпочинок в родині Потоцьких, згадує і приміщення графського палацового театру: «Театральна зала, розташована в одному з палацових крил, збудована за тим самим планом, що й у петербурзькому Ермітажі...» (Цит. за Чубіна, 2010, с.153). Таке порівняння надає нам можливість 3 цілковитою ймовірністю уявити архітектуру театру Тульчинського палацу. Це мав бути античний амфітеатр у сполученні із кулісною коробкою сцени. Напівкруглий зал для глядачів, міг 
прикрашатися нішами, ліпними медальйонами й промальовуванням колон. Тульчинський палацовий театр, як і Ермітажний театр (1784р.), мав мати більш ніж скромні розміри залу для глядачів, близько 100 глядачів і сцену-коробку незначних розмірів. Вірогідно архітектори Тульчинського маєтку, як і Дж. Кваренги - архітектор Ермітажного театру в Петербурзі, дотримуючись італійських зразків, мали оснастити планшет сцени системою кулісних машин та одноповерховим трюмом. Верх сцени розраховувався лише для зміни падуг, тому iї перекриття починалось дещо вище порталу (Базанов, 2005, с.41-42).

Поміщицько-кріпацький театр, хоч за своєю сіттю був світським, але враховуючи його соціально обмежений характер спрямування, не може вважати перехідним від шкільного до публічного. Як зазначалось вище, вертепна драма з їі загальнодоступністю виконала цю історичну місію.

Поступово в Україні починають зводитись постійні публічні театри. В. Проскуряков зазначає, що «першою постійно діючою видовищною публічною установою можна вважати невеличкий театр зі Єзуїтською брамою ([у Львові] в районі сучасної площі І. Пілкови, ближче до р. Полтви). Пристосований під театральні потреби дерев'яний будинок був ранговим театром 3 характерним діленням на яруси 3 ложами і партеровою частиною 3 галереєю. Проіснував цей театр недовго, погрожуючи з самого початку свого існування завалитися. Врешті-решт у 1783 р. був розібраний. [...] Першим стаціонарним мурованим міським театром у Львові став перебудований і упорядкований так званий Зимовий театр в переданому для цих потреб місту ще у 1787 р. францисканському костелі Св. Хреста» (Проскуряков, с.147-150).

3 огляду на суспільно-історичний контекст 1925 р. Дм. Антонович стверджує, що перший публічний театр збудовано в Харкові в 1789 р., у 1803 р. - у Києві та Одесі, у 1810 р. на кошти міста закінчено спорудження будівлі першого стаціонарного театру в Полтаві. У 20-х рр. театри були в Чернігові, Бердичеві і по інших містах України по обидва береги Дніпра. Спочатку постійних труп публічні театри не мали. Мандрівні актори їздили від ярмарку од ярмарку, з міста до міста, виступаючи поперемінно в Києві, Харкові, Кременчуці, Полтаві, Чернігові, Бердичеві та інших містах. «Перший постійний театр заведено у Харкові у 1812 р. [...]. Коло того ж часу постійний театр заведено і в Полтаві. У Катеринославі постійний театр було заведено тільки у 1847 році» (Антонович, 1925, с.57).

Дм. Антонович подає опис архітектурного рішення приміщення театру в Києві. Ошатна та вражаюча розмірами будівля Київського театру 1803 р. зведення розміщувалась на початку вулиці Хрещатик, у районі сьогоднішньої Свропейської площі. «Що до акустики, то він був надзвичайно добрим. Він мав два яруси лож, всього 32 ложі, крісла і партер за кріслами, де вже глядачі стояли; були амфітеатр і галерея; разом могло вміститися в театрі 470 чоловік» (Цит. за 1925, с.56).

Перед цим театром Київ вже мав театральне приміщення - придворний театр, що розміщувався у флігелі царської палати. Історики припускають, що в умовах відсутності в Києві загальнодоступного театру, він, цілком імовірно, міг використовуватися замість публічного (Антонович, 1925, с.56). Відомо, що в «придворному театрі давала вистави трупа Ширая» (Антонович, 1925, с.56). - 
згадуваного вище кріпацького театру поміщика Дмитра Ширая з села Спиридонова Буда Чернігівської губернії. Нажаль, відомостей про художньо-постановочні можливості сцени ні публічного, ні царського театру згадок немає.

Окрім театральних приміщень, у якості концертного майданчику Київ мав «редуту» - «В редуті мабуть сцени не було, і тільки саля з естрадою і там містилось щось подібне до клубу, бо директор редути також держав музику...» (Антонович, 1925, с.56).

Окрім стаціонарних приміщень для показу сценічних творів, використовувалися тимчасові майданчики - балагани. Так відомо, що в 1801 р. у Києві для вистав трупи Ширая «виводили умисно тимчасовий балаган» (Антонович, 1925, с.56).

Історики свідчать, що бідність і мандрівний спосіб існування переважної більшості театральних колективів в Україні на початку XIX ст. не сприяли розвитку сценографії та пов’язаної з нею театральної техніки, за винятком декількох кращих колективів, де художньо-декораційне мистецтво знаходилось на досить високому рівні. Розвиваючись під впливом зразків європейського театру XVIII ст., українська сценографія прагнула перейняти найкращі його досягнення. «Романтичний репертуар перших десятиліть українського світського театру [початок 19 ст.] вимагав багато декораційних і бутафорських ефектів, часто переносив на них всю вагу п’єси, і декорації старалися відповідати фантастичному замислу п’єси, бути фантастичними і чаруючими, але це, розуміється, не сприяло їх реалізмові» (Антонович, 1925, с.81).

На зміну романтизмові на українській сцені став панувати реалізм. У першу чергу зміна стилю торкнулася виконавського мистецтва. Але митці досить швидко відчули дисонанс між акторським виконанням i сценічною обстановкою, в якій мали існувати їхні персонажі. «Це розуміється не шкодило справжнім талановитим акторам, як Шепкін і Соленик творити реалізм виконання. [...] Подібно як талановиті виконавці часів Шекспіра, хоч грали іноді зовсім без декорацій, і тільки написом на сцені доводилося до відома глядачів, що сцена має уявити ліс, чи королівську палату, чи корчму, а тим часом ті талановиті виконавці п’єс Шекспіра часто запалом виконання робили потрясаюче враження і творили ілюзію дійсності, так і великі артисти першої половина дев'ятнадцятого віку і в умовній обстанові, і в водевільнім стилю своїм виконанням могли доходити великих реалістичних осягнень» (Антонович, 1925, с.82).

Реформатор українського театру, корифей української сцени М. Кропивницький, пропагуючи реалізм на українській сцені, працював і над змінами у драматургії та акторському мистецтві, і в режисурі та сценографії. Як новатор і борець за новий реалістичний стиль, він прагнув правди в усьому вимагав природних жестів і голосу на сцені, відповідних створюваному художньому образу костюмів, реалістичних, а не умовно-фантастичних декорацій.

Не в кращому матеріальному становищі на початку XIX ст. опинився i український театр на Галичині. Історики свідчать, що «обстанова галицькоукраїнського театру завжди була дуже не багатою, навіть убогою і служити на галицькій сцені це значило приносити себе в жертву ідеї і мистецтву. 
Починалося діло українського театру у Львові на доброхітні складки, яких за 1863 р. було зібрано 1345 гульденів 61 крейцер. Субвенцію від сейму український театр почав отримувати тільки з 1870 р. в розмірі трьох тисяч гульденів річно, і тільки через двадцять років було ту субвенцію збільшено до восьми тисяч річно. Суми до смішного все малі, - пише Дм. Антонович. i, розуміється, театр бився в тисках злиденного убожества» (1925, с.105). Повселюдні театральні злидні не могли не позначитись на художньотехнічному забезпеченні театральних постановок. Український театр на Україні Австрійській не мав власного приміщення, засуджений на постійне мандрування по галицькій та буковинській провінції» (Антонович, 1925, с.161). Цитуючи М. Кропивницького, Дм. Антонович зазначає: «Убожество обстанови вразило навіть Кропивницького, який і на Україні не звик ні до пишности, ні до достатків. «Костюми убогі, декорації неподібні, оркестр із шістьох музик, хор 3 чотирьох дівчат і п’ятьох хлопців»« (Цит. за 1925, с.105). Далі М. Кропивницький згадує, що в деяких невеликих містах вистави відбувались у стайнях - «перегородять половину стайні, начеплять декорації, посиплють пісочком... 3 одного боку за загородкою коні іржуть, а 3 другого артисти співають...» (Антонович, 1925, с.105). М. Кропивницький докладав немало зусиль, щоб покращити скрутне матеріальне становище галицько-українського театру. Українська громадськість покладала багато надій щодо поліпшення умов існуванні театру в Галичині на плани будівництва «у Львові Українського Національного Театру, але приготування до того перебила світова війна, і на власний будинок українського театру Галичина так і не здобулася» (Антонович, 1925, с.169). Певною мірою цей недолік було компенсовано зведенням незадовго до першої світової війни театрально-концертної зли в будинку музичного інституту ім. Лисенка.

Однак, при цьому, незважаючи на відсутність переслідування з боку держави i, хоч і мізерну, але щорічну субсидію, «галицький український театр не вийшов із стадії малої провінціальної трупи», «театр не проявив ні таких блискучих талановитих акторів, ні визначних драматургів, ні сталої, солідної і добре обставленої трупи» (Антонович, 1925, с.161). Дм. Антонович пропонує про технічне забезпечення мандрівних труп опосередковано судити, приміром, 3 інформації про штат галицької української трупи під орудою Біберовича у 1892 році, де із 40 працівників - директор, 15 артистів 3 хористами, 12 артисток 3 хористками, 10 музикантів, 1 суфлер, 1 машиніст, - технічним забезпеченням спектаклів займалася лише одна людина - машиніст. У злиденних умовах існування галицький український театр не мав достойного художньо-постановочного майна, мусив обходитись убогим реквізитом, набором трафаретних декорацій та парою софітів. На жаль, не знайшли собі місця в галицькому театрі сучасні постановочні досягнення і винаходи, що використовувались у компактних камерних та пересувних театрах при створенні недорогих постановок із використанням живописних полотен 3 синтетично-умовним оформленням (Антонович, 1925, с.169).

Вагомий внесок в українське театральне мистецтво, зокрема в розвиток його невід'ємного складника - театрально-декораційне мистецтво, зробив корифей української сцени М. Старицький, який увійшов в історію українського театру 
як талановитий драматург-новатор, «у своєму стилі перший i незрівняний режисер української сцени», актор - «прекрасний декламатор 3 естради і незрівняний майстер читання в голос» та директор театру, котрий свої власні немалі статки безкорисливо вложив у розвій української театральної справи (Антонович, 1925, с.111). Окрім цього, завдяки унікальній універсальності свого таланту, вмінню створювати твори театрального мистецтва як дійсно синтетичний мистецький продукт М. Старицький залишив по собі також спадщину як обдарований сценограф. «Ні один режисер не був в такій мірі художником-малярем і скульптором-декоратором на сцені, як Старицький» зазначає Дм. Антонович (1925, с.111).

Наприкінці XIX ст. в українській культурі відбулися значні події - з’явився сумнозвісний Емський указ 1876 р. - розпорядження російського імператора Олександра II від 18 (30) травня 1876 р., підписане в Бад-Емсі і спрямоване на витіснення української мови 3 культурної сфери і обмеження ії побутовим вжитком. Запроваджені мовні обмеження призвели до тимчасової дезорганізації культурного українського руху, зокрема, і в сфері театрального мистецтва «в історичному процесі розвою українського театру було зроблено короткий штучний антракт перед початком слідкуючої нової дії» (Антонович, 1925, с.122). Однак, у період заборони подекуди «на риск місцевої адміністрації, дозволялося окремі українські вистави здебільшого 3 благодійною метою» (Антонович, 1925, с.122). Також «бували подекуди вистави аматорів в приватних помешканнях при закритих дверях, тільки для знайомих без продажу квитків, а значить не потребували дозволу» (Там само). При цьому професіональні трупи не могли ставити українських вистав. На тлі боротьби царського режиму 3 українським друкованим та усним словом у 1883 р. у Київському генерал-губернаторстві українські вистави було зовсім заборонено. Відновлення показу українських вистав відбулось на правобережній Україні лише 1893 р. Разом із штучним занепадом українського сценічного слова відбувався і занепад у розвитку сценографії та іiі технічного забезпечення.

П’ять років тривала фактична заборона професійного сценічного українського слова, аж поки восени 1881 р. театральний антрепренер Г. Ашкаренко на пропозицію М. Кропивницького не відіслав міністру внутрішніх справ графу М. Лорис-Меликову телеграму із проханням «дозволити йому виставить кілька українських спектаклів, які можуть зробити йому касу, маючи на увазі український контингент суспільства, який з охотою піде на ці вистави» (Цит. за Антонович, 1925, с.125). Дозвіл було отримано. Українське суспільство, яке за роки заборони скучило за театром, зумовило шалений театральний бум - «вже в дев'ятисотих роках число труп стало так зростати, що рахувалося один час 72 українські трупи» (Антонович, 1925, с.149). Після вимушеного «відпочинку» театральні митці 3 багатократною наснагою взялись за справу відродження театральної справи, якій випала доля бути локомотивом загальноукраїнського національного руху. Корифеї українського театру, опікуючись проблемами створення нового українського побутового репертуару, не стояли осторонь щодо питань сценічного оформлення вистав. Тим паче, що проблем у цій царині було чимало. Матеріальна скрута змушувала театральні колективи вести мандрівний спосіб 
існування, але при цьому «власних декорацій з собою не возили» (Антонович, 1925, с.150). Навіть, одна із провідних театральних труп того часу під орудою М. Кропивницького «мусила грати в тій обстанові і притих декораціях, які можна було знайти в кожному з театрів» (Антонович, 1925, с.151). «Артистки і хористки мусіли мати власне одіяння як для побутового репертуару, так і для історичного. Навпаки актори і хористи мусіли мати власні тільки чоботи, решту одіяння мав антрепренер». Такий стан простежувався у переваженій більшості колективів, «тільки виїмково солідні театральні підприємства іноді мали власну обстанову і декорації, та i то в дуже обмеженому числі. Правда, - пише Дм. Антонович - 3 кінцем вісімдесятих років вже майже всі театри на Україні мали по парі декорацій, - вигляд села та середина хати, пристосованих умисне для українських труп» (1925, с.150-151). Тобто, мається на увазі, що різні п’єси виконувались різними акторами, в різних костюмах, в різному мізансценуванні та при різній режисурі, але в одних i тих самих, можна назвати, «універсальних» декораціях! Таким чином, роль сценічного оформлення у театральній постановці нівелювалась. Дм. Антонович підсумовуючи зазначає, що «взагалі обстанова і декорації - це було найслабше місце українського побутового театру з самого початку» (Антонович, 1925, с.151).

Історичною постаттю в українського театру, яка зробила значний внесок у становлення театрально-декораційного мистецтва став М. Старицький. 1883 p. в Одесі М. Старицький під своєю орудою створив антрепризу, внісши «в діло властиву його натурі широту і розмах» (Антонович, 1925, с.153). Вистави, створені колективом М. Старицького відрізнялись вдалим поєднанням «мелодраматичної красивості з етнографічним реалізмом» (Антонович, 1925, с.153). М. Старицький «виробив ту реально побутову українську сценічну обстановку, що зберігши картинність і мальовничість старих постановок, оставила їх на побутово-етнографічний грунт». Приймаючи принцип побутовизму в театрально-декораційному оформленні, він залишався прихильником створення мальовничої краси на сцені, тобто розвивав «зовнішню театральну красу на побутовій сцені» (Антонович, 1925, с.153). М. Садовський згадував: «Спектаклі були гарно обставлені з боку декорації» (Цит. за Антонович, 1925, с.153). На жаль, статків М. Старицького не вистачило і на десяток років, але своєю творчою діяльністю він вплинув на становлення багатьох провідних театральних колективів в Україні 19 ст.

Закладені М. Старицьким і підтримані його послідовниками принципи сценічної творчості були високо оцінені сучасниками. Вистави кращих театральних труп порівнювали 3 постановками Мейнінгенського театру. Фактично «театр Мейнінгенський і театр український переслідували однакові ідеали і можна сказати, що постанова український труп - це єсть побутово розроблена постанова Мейнінгенців. Розуміється, про вплив одних на других говорити не приходиться. Це просто в один час однакові ідеї опанували передовими театральними діячами в різних кутках Європи, вони зросли із комплексу аналогічних причин і появили багато спільного в наслідках» (Антонович, 1925, с.154-155). Отже, можна стверджувати про розвиток українського театрального мистецтва XIX ст. у контексті європейського мистецького процесу. Український театр протягом XVII - XIX ст. пройшов 
крізь всі фази, всі течії, що проходив європейський театр: псевдокласицизм, романтизм, сентименталізм, побутовий реалізм, натуралізм, соціальна драма, символізм (Антонович, 1925, с.222). В силу історичних та політичних причин український театр, хоч і не завжди синхронізовано, але розвивався за тими самими законами історичного мистецького процесу, що і європейський театр. «В добу побутового театру український театр неперечно вибивався наперед в процесі розвою європейської театральної творчості» (Антонович, 1925, с.223).

Вивчаючи особливості впливу художньо-постановочних засобів оформлення сценічного простору на розвиток українського театрального мистецтва, не можна оминути питання українського театрального руху на селі. Театральне мистецтво на межі XIX - XX ст. отримало на селі сприятливий соціально-культурний грунт. Особливо це проявилось після революційної хвилі 1905 р., коли для українського слова настали певні полегшення, коли активізували свою діяльність осередки громадської організації «Просвіта». На фоні пом'якшення антиукраїнської політики уряду «почали будувати власні будинки 3 театральними салями» (Антонович, 1925, с.174), що сприяло створенню в українських селах постійних народних театрів, що існували коштом та зусиллями самих селян. Досить швидко настав період реакції, але театральний рух у селах продовжував поширюватись, згодом вплинувши і на створення театральних аматорських товариств у робітничому колі.

На противагу правобережній Україні, де «український народний театр зазнавав багато труднощів, переслідувань і заборон, на Україні Австрійській шлях для народного театру був вільніше i розвивався він нормальніше» (Антонович, 1925, с.174). У Галичині до початку XX ст. збереглися пережитки шкільного театру, зберігся тут і вертеп як ляльковий, так і у формі живого акторського виконання. Але перехід до світського театру відбувався під впливом театру правобережної України. «На село цей новий театр переносила спочатку свідома українська інтелігенція» (Антонович, 1925, с.174). Ці новостворені сільські галичанські театри були непоодинокі. Щодо матеріально-технічного забезпечення, то вони мали відносно достойне забезпечення: власні постійні театральні приміщення із необхідним оснащенням i глядацькою залою, свої декорації, створені місцевими художниками.

Окрім селянського i робітничого середовища, «рух аматорського українського театру став пробиватися і в солдатські касарні» (Антонович, 1925, с.176). Свідченням стійкої соціальної прихильності різних верств українського населення до театрального мистецтва може слугувати факт, що під час Першої світової війни на території Німеччини та Австрії в украӥнських таборах для полонених силами самих в’язнів створювались театри, хоча не без підтримки табірного керівництва та свідомого українства. Серед полонених часто були «бувші актори, співаки, іноді малярі-декоратори, іноді поети-драматурги» (Антонович, 1925, с.176). Варто зауважити, що «завжди в кожному українському таборі обов'язково був свій театр» (Антонович, 1925, с.176-177). Так, наприклад, у Зальцведелі товариство «Народній театр» збудувало в таборі дуже добру театральну салю, яка вміщала до тисячі глядачів. Між виконавцями знайшлися дуже здібні аматори, між якими особливе визначився п. Березняк, 
що сам і декорації розписував» (Антонович, 1925, с.177). Або, наприклад, найбільший із австрійських таборів для полонених у Фрайштаті в Австрії також мав свій театр, створений товариством ім. І. Котляревського. «Для театру тут пристосували окремий барак, який досить ошатно було удекоровано» (Антонович, 1925, с.177). Любов до театрального мистецтва стала притаманна усім соціальним прошаркам, стала невід'ємною складовою життя суспільства. Поширення театрального мистецтва у формі аматорського сприяло щонайширшому розкриттю різних особистих талантів в населення - від поетичного, режисерського, виконавського (артистичного, вокального, хореографічного) до малярського та архітектурно-інженерного. Адже художньо-постановочне забезпечення вистав $є$ їхньою неодмінною складовою.

На початку XX ст. у розвитку українського театрального мистецтва сталась знакова подія - у 1904 р. під орудою М. Старицької, старшої дочки М. Старицького при музичній школі М. Лисенка в Києві було засновано драматичну українську школу. Засновники нової драматичної школи покладали надію на апробацію в іï стінах нового не побутового репертуару та підготовку молодих виконавців. «При школі було обставлено дуже приличну хоч невелику сцену, для лаштунків дуже дотепно комбінувалися кольорові полотна і мальовані декорації» (Антонович, 1925, с.202). Варто зазначити, що поряд 3 фаховими практичними і теоретичними предметами - теорія драми, історія української та європейської драми, історія костюму, історія зовнішнього вигляду людини, теорія i практика гриму, танцю, фехтування, музики викладались «теорія світлових і кольорових комбінацій, стилі обстанов». Означений факт свідчить про високопрофесійний фаховий підхід засновників драматичної школи і розуміння ними важливої ролі образотворчого рішення вистави в процесі створення театральної постановки.

Наукова новизна. У дослідження, що виконане переважно за матеріалами, зібраними та систематизованими видатним істориком театру Дм. Антоновичем у монографії «Триста років українського театру», уперше осмислюється еволюція театрального простору українського театру з погляду архітектурнотехнічного забезпечення його пластичного оформлення.

Висновки. Виходячи із вищезазначеного можна стверджувати:

1. Твір сценічного мистецтва, маючи матеріалізовану природу, існує в певному сценічному просторі, обов’язковою характеристикою якого $€$ наявність у ньому дії.

2. Дм. Антонович виокремлює за триста років історії українського театру від початку XVII - до початку XIX ст.. кілька його різновидів: шкільний театр, церковно-релігійна драма, вертеп, кріпацький театр, публічний театр, «редути», балагани, сільські народні театри, театри мистецьких освітніх закладів. Для кожного з них існували специфічні форми та засоби пластичного оформлення сценічного простору.

3. Для українського театру характерним був простір i закритого, і відкритого типу. Так, театральним простором для показу вистав шкільного театру слугували і приватні оселі, громадські місця, культові споруди закритий тип, і локації з використанням природного ландшафту - відкритий. У закритому сценічному просторі, особливо в приміщеннях духовних шкіл та 
семінарій, у культових спорудах для пластичного оформлення вистав поряд iз костюмами та реквізитом широко застосовувались різні предметні комплекси. Для організації вистав просто неба застосовувалися декорації спрощеномобільного характеру.

4. При виставленні в приміщені церкви містеріальної драми часто використовувалися світлові ефекти; тут до традиційних засобів пластичного оформлення сценічного простору належали і предмети культу, і виготовлені спеціально для показу вистав.

5. Засобом пластичного оформлення сценічного простору української вертепної вистави була спеціальні двоповерхова мобільна скринька, де дія розгорталася з використанням ляльок за умовно знятою «четвертою стіною».

6. Мандрівний спосіб організації діяльності переважної більшості театральних колективів в Україні на початку XIX ст., їхня бідність за деякими винятками не сприяли розвитку мистецтва сценографії та пов'язаної 3 нею театральної техніки,

7. Матеріально-технічне забезпечення сільських театрів, зокрема в Галичині, було відносно достойним: власні постійні театральні приміщення iз необхідним оснащенням, глядацькою залою, свої декорації, створені місцевими художниками.

Проведене дослідження вузько спрямоване на детальне вивчення засобів пластичного оформлення сценічного простору на матеріалах, зібраних, систематизованих та проаналізованих переважно Дм. Антоновичем у його монографії «Триста років українського театру». Натомість автор цілком свідомий того, що запропонована для вивчення проблема не може обмежуватися таким досить вузьким спектром історіографії. Тому справедливим буде в перспективі розширити і джерельну базу дослідження засобів пластичного оформлення сценічного простору в історії українського театру, залучаючи вітчизняні та зарубіжні літературні джерела, інший іконографічний матеріал, і розширити його хронологічні межі від першої чверті XIX ст. до сьогодення. У цьому пріоритетним може бути акцентування уваги на еволюції, зокрема, сценографічного простору в українському театрі.

\section{Список посилань}

Антонович, Д., 1925. Триста років українського театру. 1619-1919. Прага: Український громадський видавничий фонд.

Астафьева, Т. В., 2011. Новые технологии в современном постановочном процессе (на материале театрального искусства Санкт-Петербурга).Кандидат наук. СанктПетербургский гуманитарный университет профсоюзов.

Базанов, В.В., 2005. Технология сиеньы. Москва: Імпульс-свет.

Веселовська, Г.І., 2010. Украӥнський театральний авангард. Київ: Фенікс.

Крипчук, М.В., 2011.Проблеми створення масового театралізованого видовища (принципи художнього оформлення) Наукові записки Тернопільського національного педагогічного університету імені Володимира Гнатюка. Серія: Мистеитвознавство, 2, с.163-168. [online] Доступно: <http://nbuv.gov.ua/UJRN/NZTNPUm_2011_2_29> [Дата звернення 11 грудня 2018]. 
Крипчук, М.В., 2018. Сценічний простір просто неба як складова сучасного театралізованого видовища. Вісник Національної академї керівних кадрів культури i мистецтв, 2, с.229-233. [online] Доступно: <http://nbuv.gov.ua/UJRN/ vdakkkm_2018_2_50> [Дата звернення 11 грудня 2018].

Островерх, О., 2007. Еволючиія просторових систем украӥнського драматичного театру: типи організації, функиії, людина (від натуралізму до авангарду). Кандидат наук. Інститут мистецтвознавства, фольклористики та етнології ім. М.Т. Рильського НАН України.

Паві, П., 2006. Словник театру. Львів: Видавничий центр Львівського національного університету імені Івана Франка.

Проскуряков, В.І., 2002. Принщипи розвитку архітектурної типології украӥнського театру. Доктор наук.Національний університет «Львівська політехніка».

Чечель, Н.П., 2005. Дискурс стилю в ретроспективі украӥнської видовищної $i$ драматичної культури. Доктор наук. Київський національний університет імені Тараса Шевченка.

Чубіна, Т.Д., 2010. Тульчинський палац Потоцьких як осередок культурно-мистецького життя. Наукові праці [Чорноморського державного університету імені Петра Могили]. Серія: Історія, 127(140), c.149-157. [online] Доступно: <http://nbuv.gov.ua/UJRN/Npchdui_2010_140_127_29> [Дата звернення 01 грудня 2018].

\section{References}

Antonovych, D., 1925. Trysta rokiv ukrainskoho teatru. 1619-1919 [Three hundred years of Ukrainian theater. 1619-1919]. Prague: Ukrainskyi hromadskyi vydavnychyi fond.

Astaf'eva, T.V., 2011. Novye tehnologii $v$ sovremennom postanovochnom processe (na materiale teatral'nogo iskusstva Sankt-Peterburga) [New technologies in the modern production process (on the material of the theatrical art of St. Petersburg).]. PhD. St. Petersburg Humanitarian University of Trade Unions.

Bazanov, V.V., 2005. Tekhnologiya stseny [Technology scenes]. Moscow: Impul's-svet.

Veselovska, H.I., 2010. Ukrainskyi teatralnyi avanhard [Ukrainian theatrical avantgarde]. Kyiv: Feniks.

Krypchuk, M.V., 2011. Problemy stvorennia masovoho teatralizovanoho vydovyshcha (pryntsypy khudozhnoho oformlennia) [Problems of creating a massive theatrical spectacle (principles of artistic design)] Naukovi zapysky Ternopilskoho natsionalnoho pedahohichnoho universytetu imeni Volodymyra Hnatiuka. Seriia: Mystetstvoznavstvo, 2, c.163-168. [online] Available at: <http://nbuv.gov.ua/UJRN/NZTNPUm_2011_2_29> [Accessed 11 December 2018].

Krypchuk, M.V., 2018. Stsenichnyi prostir prosto neba yak skladova suchasnoho teatralizovanoho vydovyshcha [Scenic space of the sky as part of a modern theatrical spectacle]. Visnyk Natsionalnoi akademii kerivnykh kadriv kultury i mystetstv, 2, pp.229-233. [online] Available at: <http://nbuv.gov.ua/UJRN/vdakkkm_2018_2_50> [Accessed 11 December 2018].

Ostroverkh, O., 2007. Evoliutsiia prostorovykh system ukrainskoho dramatychnoho teatru: typy orhanizatsii, funktsii, liudyna (vid naturalizmu do avanhardu) [Evolution of the openspace systems of the Ukrainian dramatic theater: the types of organizations, functions, people (from naturalism to the avant-garde)] $\mathrm{PhD}$. Institute of Art Studies, Folklore Studies and Ethnology. M.T. Rilsky National Academy of Sciences of Ukraine.

Pavi, P., 2006. Slovny'k teatru [The theater dictionary]. Lviv: Publishing Center of the Ivan Franko National University of Lviv. 
Proskuriakov, V.I., 2002. Pryntsypy rozvytku arkhitekturnoi typolohii ukrainskoho teatru [Principles of development of the architectural typology of the Ukrainian theater]. D.Ed. National University «Lviv Polytechnic».

Chechel, N.P., 2005. Dyskurs styliu v retrospektyvi ukrainskoi vydovyshchnoi i dramatychnoi kultury [Discourse of style in the retrospect of Ukrainian spectacle and dramatic culture]. $\mathrm{PhD}$. Kyiv National Taras Shevchenko University.

Chubina, T.D., 2010. 'Tulchynskyi palats Pototskykh yak oseredok kulturno-mystetskoho zhyttia.' [Tulchin Palace Pototsky as a center of cultural and artistic life.]. Naukovi pratsi [Chornomorskoho derzhavnoho universytetu imeni Petra Mohyly]. Seriia: Istoriia, 127(140), pp.149-157. [online] Available at: <http://nbuv.gov.ua/UJRN/Npchdui_2010_140_127_29> [Accessed 01 December 2018].

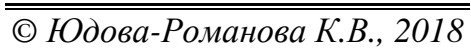


Iudova-Romanova Kateryna, $P h D$ in Art Studies, Associate Professor, Doctoral Student, Kyiv National University of Culture and Arts, Kyiv, Ukraine

\section{PLASTIC FORMATION WAYS OF SCENIC SPACE (FROM THE UKRAINIAN THEATER HISTORY)}

The purpose of the article is to consider the theatrical space evolution of the Ukrainian theater in terms of architectural and technical provision of its plastic design. The author has used the following research methods: a critical analysis is in the scientific literature development on the theatrical art history, architecture and stage design in order to recapture information on the research topic; art analysis is for the plastics correlation of the stage space of performances and their informative content; synthesis is for combining various characteristics of the spatial and technical support of the Ukrainian theater in the period of XVII-XIX centuries; induction is to study, albeit fragmentary, but typical examples of spatial and technical support for the exhibitions in this period; hypothetical, systemic and generalizing are to formulate conclusions. Scientific novelty. The study focuses on the theater space evolution in the Ukrainian theater from the point of view of its plastic design. Conclusions. Stage art works have an effective structure, materialize in a certain stage space; according to the Ukrainian theater varieties in the XVII-XIX centuries they are: school theater, church-religious drama, vertep, serf theater, public theater, home theater, «redoubts», balagans, rural folk theaters, artistic educational establishments theaters; there were specific forms and plastic design means of their stage space; characteristic for the Ukrainian theater is the closed space (private dwellings, public places, religious buildings), which is characterized by wide use of subject complexes and open types (the natural landscape location) with simplified-mobile character decorations; performances characteristic in the premises of the church was the light effects use, cult attributes and theatrical propaganda; the plastic design means of the scenic space in the vertebrate two-story mobile box with the conventionally shot «fourth wall» and a doll characters set; a wandering way of organizing activities and the economic difficulty of the vast majority in theatrical groups in Ukraine at the beginning of the XIX century did not contribute to the scenography development and theatrical technique; the material and technical support of rural theaters, in particular in Galicia, it was relatively worthwhile.

Key words: Ukrainian theater history; scenic space; plastic design means; Dmitry Antonovich. 
Юдова-Романова Екатерина Владимировна, кандидат искусствоведения, дочент, Киевский национальный университет культуры и искусств, Киев, Украина

\section{СРЕДСТВА ПЛАСТИЧЕСКОГО ОФОРМЛЕНИЯ СЦЕНИЧЕСКОГО ПРОСТРАНСТВА (ИЗ ИСТОРИИ УКРАИНСКОЙ ТЕАТРА)}

Целью статьи является рассмотрение эволюции театрального пространства украинского театра с точки зрения архитектурно-технического обеспечения его пластического оформления. Автором использованы следующие методы исследования: критического анализа - в разработке научной литературы по истории театрального искусства, архитектуры и сценического дизайна с целью реферирования информации на тему исследования; искусствоведческого анализа - для соотнесения пластики сценического пространства представлений и их содержательного наполнения; синтеза для сочетания различных характеристик пространственно-технического обеспечения украинского театра периода XVII - XIX веков.; индукционный - для изучения хотя и фрагментарных, но типичных примеров пространственно-технического обеспечения спектаклей указанного периода; гипотетический, системный и обобщающий - для формулирования выводов. Научная новизна. В исследовании впервые осмысливается эволюция театрального пространства украинского театра с точки зрения средств его пластического оформления. Выводы. Произведения сценического искусства, имея действенную структуру, материализуются в определенном сценическом пространстве; в соответствии с разновидностями украинского театра XVII - XIX веков - школьный театр, церковно-религиозная драма, вертеп, крепостной театр, публичный театр, домашний театр, «редут», балаганы, сельские народные театры, театры художественных учебных заведений - существовали специфические формы и средства пластического оформления их сценического пространства; для украинского театра характерным было пространство как закрытого (частные дома, общественные места, культовые сооружения), которому присущи широкое применение предметных комплексов, так и открытого типов (локации природного ландшафта) с декорациями упрощенно-мобильного характера; характерным для спектаклей в помещениях церкви было использование световых эффектов, культовой атрибутики и театральной бутафории; средства пластического оформления сценического пространства вертепа двухэтажный мобильный ящик с условно снятой «четвертой стеной» и набор кукольных персонажей; странствующий способ организации деятельности и экономические трудности подавляющего большинства театральных коллективов в Украине в начале XIX в. не способствовали развитию сценографии и театральной техники; материальнотехническое обеспечение сельских театров, в частности на Галичине, было относительно достойным.

Ключевые слова: история украинского театра; сценическое пространство; средства пластического оформления; Дмитрий Антонович. 